DOI: 10.18276/sip.2016.43/3-29

\title{
Mirosław Pacut*
}

Uniwersytet Ekonomiczny w Katowicach, Wydział Zarządzania, Katowice, Polska

\section{ZACHOWANIA NABYWCZE POLSKICH E-KONSUMENTÓW NA RYNKU}

\section{Streszczenie}

Zachowania nabywcze e-konsumentów są zjawiskiem o znacznej dynamice, podlegającym istotnym zmianom dokonującym się wraz z szybko ewoluującą technologią teleinformatyczną. Szybko wzrasta wartość e-zakupów oraz odsetek konsumentów deklarujący ich dokonywanie, a także znaczenie internetu jako źródła informacji wykorzystywanego w procesie podejmowania decyzji zakupowych. Możliwości oferowane przez technologie teleinformatyczne powodują przy tym, że internet staje się wygodnym instrumentem optymalizacji decyzji nabywczych konsumentów. Artykuł stanowi próbę identyfikacji podstawowych przejawów zachowań polskich e-konsumentów oraz uchwycenia tendencji w zakresie zmian tych zachowań na przestrzeni ostatnich lat.

Słowa kluczowe: zachowania konsumentów, e-konsumenci, zachowania nabywcze

\section{Wstęp}

Internet funkcjonuje jako powszechne medium komunikacyjne już od niemal ćwierć wieku, stopniowo przeobrażając wiele obszarów funkcjonowania współczesnych społeczeństw. Określany jako „,społeczeństwo informacyjne”, oparty na swobodnej i nieskrępowanej, globalnej wymianie informacji, nowy model funkcjonowania społeczeństw stanowić ma wręcz kolejny etap ich rozwoju stojący w opozycji do

* Adres e-mail: miroslaw.pacut@ue.katowice.pl. 
społeczeństwa epoki industrialnej (Goban-Klas, Sienkiewicz, 1999). Z ekonomicznego punktu widzenia istotą tych przeobrażeń stało się nie tylko stworzenie nowej platformy komunikowania się pomiędzy podmiotami rynkowymi, ale przede wszystkim wykreowanie nowego środowiska wymiany wartości z całą przynależną mu infrastrukturą. Postępująca wirtualizacja procesów gospodarczych, w tym przede wszystkim handlu detalicznego, doprowadziła w konsekwencji do fundamentalnych nieraz zmian w zachowaniach współczesnych konsumentów. Celem artykułu jest próba identyfikacji podstawowych przejawów zachowań polskich e-konsumentów oraz uchwycenia tendencji w zakresie zmian tych zachowań na przestrzeni ostatnich lat.

Jednym z najistotniejszych, wynikających z pojawienia się hipermedialnego modelu komunikowania czynników determinujących przemiany w zachowaniach konsumentów było z pewnością znaczne ograniczenie (a w niektórych przypadkach niemal całkowita likwidacja) barier w dostępie do informacji rynkowej. Rewolucyjny wzrost przejrzystości rynków konsumpcyjnych przyczynił się przy tym zarówno do wzrostu poziomu racjonalności poszczególnych decyzji nabywczych, jak i poszerzania się zakresu kategorii produktowych objętych względnie rozbudowanym modelem podejmowania decyzji. Dodatkowym stymulatorem tych zmian była pojawiająca się możliwość przekazywania informacji nie tylko w układzie konsumentprzedsiębiorstwo, ale także swobodna i nieograniczona wymiana opinii pomiędzy samymi konsumentami ( $w$ tym dzielenie się doświadczeniami i ocenami poszczególnych ofert rynkowych), której rozkwit nastąpił wraz z pojawieniem się serwisów internetowych opartych na modelu web 2.0.

Drugą, jak się wydaje nie mniej istotną płaszczyzną generowanych przez rozwój technologii teleinformatycznych przemian w zachowaniach konsumentów jest wykształcenie się zupełnie nowych, przynależnych przestrzeni wirtualnej kanałów marketingowych (komunikacyjnych i dystrybucyjnych) przeobrażających niemal całkowicie przebieg procesu składania zamówień i uzgadniania warunków oferty, a także przewartościowujących znaczenie poszczególnych kanałów dystrybucji (skróceniu drogi pomiędzy producentem a konsumentem towarzyszą jednocześnie istotne modyfikacje w zakresie logistyki dystrybucji). 


\section{E-konsument $\mathrm{i}$ jego zachowania nabywcze}

Wraz ze zmianami w zakresie funkcjonowania rynków konsumpcyjnych wygenerowanymi przez stopniowe upowszechnianie się sieci internetowej i wzrastający stopień jej wykorzystania w procesach gospodarczych, w tym związanych z konsumpcją, pojawiła się potrzeba kategoryzacji nowych zjawisk charakterystycznych dla wirtualnych obszarów gospodarki. Do literatury wprowadzono wówczas między innymi pojęcia e-handlu (w tym e-hurtu i e-detalu), e-nabywcy, e-konsumenta, e-zachowań konsumpcyjnych - zrazu używane nie do końca konsekwentnie i jednoznacznie, co zresztą charakterystyczne dla nowych kategorii nieposiadających od razu precyzyjnie ustalonego zakresu pojęciowego. O ile na przykład pojęcie e-handlu czy e-zakupów nie budzi właściwie wątpliwości, to kategoria e-konsumenta bywa definiowana różnorako. W węższym ujęciu e-konsumenta definiuje wyłącznie sam akt dokonania zakupu w internecie w celu zaspokojenia potrzeb konsumpcyjnych. Można jednak również przyjąć szerszy zakres tego pojęcia - zakładający, że e-konsumentem jest każdy, kto wykorzystał internet na jakimkolwiek etapie procesu podejmowania decyzji nabywczej - niekoniecznie dokonując w sieci samego zakupu, ale także na przykład wyłącznie poszukując ofert lub/i informacji o ich parametrach rynkowych (cenie, właściwościach produktu, usługach dodatkowych, sposobach dystrybucji itp.), komunikując się ze sprzedawcami czy wymieniając opinie z innymi konsumentami (Jaciow, Wolny, 2011).

Zachowania e-konsumentów - w zależności od przyjętej interpretacji - w większym lub mniejszym zakresie nakładają się więc pojęciowo na ogólnie rozumiane zachowania konsumentów, w pewnym zakresie stanowią natomiast kategorię odrębną, definiującą sposoby zachowań specyficzne wyłącznie dla zakupów internetowych. I pomimo iż historia badania tych zachowań nie jest długa, bo sięga co najwyżej dwóch dekad wstecz, widać wyraźnie, że podlegają one w swej relatywnie krótkiej historii dynamicznym zmianom wraz z szybko ewoluującą technologią (nowe rozwiązania w zakresie przekazywania informacji, realizacji płatności czy rozwiązań logistycznych), ale także upowszechnianiem się samego dostępu do internetu.

Obraz zachowań e-konsumentów różni się więc znacząco od tego sprzed kilku nawet lat. Podstawową płaszczyzną zmian jest szybkie poszerzanie się samego zakresu zjawiska dokonywania zakupów w sieci (tabela 1) napędzanego przez wzrost dostępności internetu wśród polskich gospodarstw domowych (będący efektem rozwoju infrastruktury telekomunikacyjnej oraz spadku cen korzystania z łączy). Dostępem do internetu dysponuje obecnie 3/4 gospodarstw domowych (z których 
prawie $95 \%$ posiada dostęp szerokopasmowy konieczny dla swobodnego korzystania z sieci), ponad 1/3 mieszkańców Polski dokonuje zakupów w sieci (dla porównania w 2007 r. - 16\%), a co drugi z nich wykorzystuje internet do pozyskiwania informacji o ofertach rynkowych. Znaczenie pozyskanych w ten sposób informacji w procesie podejmowania decyzji nabywczych wzrasta wraz z upowszechnianiem się dostępu do internetu. W 2007 roku korzystało z nich niespełna 30\% nabywców (GUS 2011, 2014, 2015). Konsekwencją globalnego zasięgu przestrzeni hipermedialnej jest także wzrastający odsetek zakupów transgranicznych. W 2015 roku co siódmy polski użytkownik internetu zadeklarował dokonywanie zakupów w zagranicznych serwisach (Gemius, 2015).

Warto przy tym zauważyć, że znacznie szybciej niż odsetek konsumentów dokonujących zakupów w sieci rośnie łączna wartość tych zakupów. W okresie ostatnich lat rosła ona rocznie średnio o około 20\%, osiągając obecnie prawie $24 \mathrm{mld}$ zł, co stanowi 6,8\% łącznych obrotów handlu detalicznego (Euromonitor, 2015).

Tabela 1. E-konsumenci i e-zakupy w Polsce - podstawowe dane statystyczne

\begin{tabular}{|l|c|c|c|c|c|c|c|c|c|}
\hline \multicolumn{1}{|c|}{ Wyszczególnienie } & 2007 & 2008 & 2009 & 2010 & 2011 & 2012 & 2013 & 2014 & 2015 \\
\hline $\begin{array}{l}\text { Dostęp gospodarstw domowych } \\
\text { do internetu [\%] }\end{array}$ & 41 & 48 & 59 & 63 & 67 & 70 & 72 & 75 & 76 \\
\hline $\begin{array}{l}\text { Odsetek osób dokonujących } \\
\text { zakupów on-line [\%] }\end{array}$ & 16 & 18 & 23 & 29 & 30 & 30 & 32 & 34 & 48 \\
\hline $\begin{array}{l}\text { Odsetek osób wyszukujących } \\
\text { w internecie informacji } \\
\text { o towarach i usługach [\%] }\end{array}$ & 27 & 33 & 29 & 39 & 44 & 47 & 45 & 50 & 42 \\
\hline Wartość e-zakupów netto [mld zł] & 5,6 & 7,3 & 8,6 & 9,9 & 11,8 & 14,1 & 16,4 & 19,7 & 23,6 \\
\hline Wartość e-zakupów per capita [zł] & 146 & 191 & 225 & 258 & 305 & 366 & 426 & 510 & 613 \\
\hline
\end{tabular}

Źródło: opracowanie własne na podstawie danych GUS (2011, 2014, 2015) oraz Euromonitor (2015).

Wraz z upowszechnianiem się zakupów internetowych dość istotnie zmieniają się także postawy wobec e-zakupów. Wyraźnie wzrasta odsetek osób dostrzegających niskie ceny w sklepach internetowych oraz doceniających oszczędność czasu charakteryzującą zakupy on-line. W nieznacznym stopniu zmianie ulegają natomiast opinie o wysokim stopniu skomplikowania oraz ryzyku związanym z zakupami w sieci (tabela 2). 
Tabela 2. Postawy wobec zakupów w internecie [\% odpowiedzi twierdzących]

\begin{tabular}{|l|c|c|c|c|c|c|c|}
\hline \multicolumn{1}{|c|}{ Zakupy w internecie: } & 2008 & 2009 & 2010 & 2011 & 2012 & 2014 & 2015 \\
\hline Są tańsze niż zakupy w sklepach tradycyjnych & 53 & 51 & 59 & 58 & 59 & 62 & 63 \\
\hline $\begin{array}{l}\text { Zajmują mniej czasu niż zakupy w sklepach } \\
\text { tradycyjnych }\end{array}$ & 49 & 47 & 67 & 60 & 61 & 60 & 61 \\
\hline Są ryzykowne & 46 & 44 & 48 & 48 & 42 & 44 & 39 \\
\hline Są skomplikowane & 11 & 11 & 20 & 21 & 19 & 17 & 13 \\
\hline
\end{tabular}

Źródło: opracowanie własne na podstawie danych Gemius (2012, 2014, 2015).

Analizując zachowania e-konsumentów, warto zwrócić również uwagę na udział poszczególnych kategorii produktowych w zakupach internetowych (tabela 3). Zdecydowanie najbardziej popularne są zakupy odzieży i sprzętu sportowego (deklaruje je prawie 2/3 osób dokonujących zakupów w sieci), najrzadziej kupowane są natomiast - co dość zaskakujące - filmy i muzyka (8\%), a także sprzęt komputerowy (11\%) i oprogramowanie (12\%). Łatwo zaobserwować też pewne trendy - wyraźnie zauważalny jest przede wszystkim wzrost odsetka osób dokonujących zakupu odzieży i sprzętu sportowego (o 24 p.p.) oraz usług turystycznych (o 16 p.p.). W istotnym stopniu wzrósł także odsetek kupujących bilety na imprezy sportowe i kulturalne. Znacznie zmniejszył się natomiast odsetek kupujących w internecie książki i czasopisma (o 14 p.p), filmy i muzykę (o 13 p.p.). Nieznacznie zmniejszył się również zasięg zakupów sprzętu elektronicznego i komputerowego. W odniesieniu do pozostałych kategorii produktowych na przestrzeni okresu 2007-2015 nie zanotowano zbyt istotnych zmian.

Tabela 3. Odsetek e-konsumentów dokonujących w internecie zakupów poszczególnych kategorii produktowych [\% kupujących w sieci]

\begin{tabular}{|l|c|c|c|c|c|c|c|c|c|}
\hline \multicolumn{1}{|c|}{ Kategorie produktów } & 2007 & 2008 & 2009 & 2010 & 2011 & 2012 & 2013 & 2014 & 2015 \\
\hline Ubrania i sprzęt sportowy & 38 & 45 & 47 & 49 & 52 & 53 & 57 & 61 & 62 \\
\hline Pozostałe wyposażenie* & 29 & 34 & 41 & 43 & 41 & 45 & 44 & 42 & 34 \\
\hline Książki, czasopisma & 34 & 30 & 30 & 31 & 29 & 27 & 28 & 23 & 20 \\
\hline Sprzęt elektroniczny & 24 & 23 & 23 & 20 & 16 & 19 & 17 & 19 & 18 \\
\hline Sprzęt komputerowy & 13 & 15 & 14 & 12 & 10 & 11 & 11 & 14 & 11 \\
\hline Artykuły spożywcze, kosmetyki & 17 & 17 & 19 & 19 & 19 & 21 & 24 & 24 & 19 \\
\hline Filmy, muzyka & 21 & 15 & 19 & 20 & 16 & 17 & 16 & 12 & 8 \\
\hline Bilety na imprezy sportowe/kulturalne & 10 & 10 & 15 & 17 & 14 & 15 & 16 & 16 & 17 \\
\hline Oprogramowanie, gry & 14 & 10 & 18 & 18 & 16 & 16 & 16 & 14 & 12 \\
\hline Wczasy, wycieczki, noclegi, bilety & 10 & 9 & 12 & 13 & 17 & 12 & 19 & 19 & 26 \\
\hline
\end{tabular}

* meble, pojazdy, artykuły AGD, ogrodowe, narzędzia, zabawki, biżuteria

Źródło: opracowanie własne na podstawie danych GUS (2011, 2014, 2015). 
Współczesne tempo życia skłania konsumentów do poszukiwania rozwiązań czasooszczędnych $-\mathrm{z}$ ich punktu widzenia zakupy powinny być szybkie, wygodne, a także możliwe do zrealizowania w dowolnym miejscu i czasie. Przedzierzgnięcie się konsumenta w e-konsumenta zapewnia spełnienie tych wymagań w stopniu wcześniej niespotykanym. Technologie teleinformatyczne odgrywają bowiem trudną do przecenienia rolę $\mathrm{w}$ zapewnianiu konsumentom dogodności zarówno w odniesieniu do procesu podejmowania decyzji nabywczych, jak i samych aktów zakupu i konsumpcji. Jednym z podstawowych jej przejawów jest nieosiągalna w tradycyjnej gospodarce przejrzystość rynku - ogromne ilości informacji rynkowych są dostępne dla konsumenta nieomal na wyciągnięcie reki, a koszt (tak materialny, jak i pozamaterialny) ich pozyskania jest niski. Internet staje się istotnym źródłem informacji o dostępnych na rynku ofertach $\mathrm{i}$ ich parametrach, a także wygodnym instrumentem optymalizacji decyzji nabywczych.

Podstawowym narzędziem wykorzystywanym w tym celu są porównywarki cen, z których korzysta prawie 2/3 kupujących on-line. Komunikacja w przestrzeni hipermedialnej pozwala przy tym nie tylko na pozyskiwanie sformalizowanej informacji rynkowej (jak ta o cenach), ale również wymianę opinii użytkowników na temat poszczególnych ofert. Serwisy służące wymianie opinii i doświadczeń e-konsumentów (ogólnotematyczne i specjalistyczne) są tylko nieco mniej popularne od porównywarek cen (które też mają zaimplementowaną tę funkcję jako dodatkową) - korzysta z nich niecałe 60\% osób kupujących w sieci (Gemius, 2015). Dążenie do optymalizacji decyzji zakupowych przejawia się także poprzez korzystanie z zakupów grupowych. Pojawienie się i szczyt popularności serwisów oferujących taki model zakupów przypadały na początek obecnej dekady (w 2011 r. co trzeci kupujący on-line deklarował skorzystanie z tej formy zakupów), a obecnie wydają się odchodzić powoli w zapomnienie (korzysta z nich nieco ponad 10\% e-nabywców) (Gemius, 2014). Warto przy okazji zauważyć, że upowszechnienie się modelu podejmowania decyzji na podstawie szczegółowego porównania (przede wszystkim cen) przyczynia się do spadku lojalności e-konsumentów wobec dostawców (Kasriel-Alexander, 2015).

Niewątpliwie interesującym w kontekście optymalizacji decyzji nabywczych e-konsumentów zjawiskiem jest hybrydowe wykorzystywanie w procesach decyzyjnych informacji pozyskanych w sieci i poza nią oraz hybrydowe wykorzystanie internetowych i tradycyjnych kanałów dystrybucji. Zjawisko to może się przejawiać na dwa sposoby - określane odpowiednio mianem ROPO i odwróconego ROPO, zwanego też efektem showroomingu (Tkaczyk, 2015). Model ROPO polegają- 
cy na pozyskiwaniu informacji w internecie, a następnie zakupie $\mathrm{w}$ tradycyjnym detalu dotyczy według różnych badań od 36\% (Consumer Barometer, 2015) do 70\% (Opiniac, 2015) polskich użytkowników internetu. Model odwrotny (poszukiwanie informacji w tradycyjnych sklepach, a następnie zakup on-line) jest wyraźnie mniej popularny, dotyczy jedynie 11\% internautów (rysunek 1). Efekt ROPO w największym stopniu odnosi się do (co dosyć oczywiste) nieruchomości, a także usług turystycznych, sprzętu elektronicznego i komputerowego, natomiast efekt odwróconego ROPO - usług transportowych oraz muzyki.

Rysunek 1. Hybrydowe wykorzystanie internetowych i tradycyjnych źródeł informacji i kanałów dystrybucji (ROPO i odwrócone ROPO)

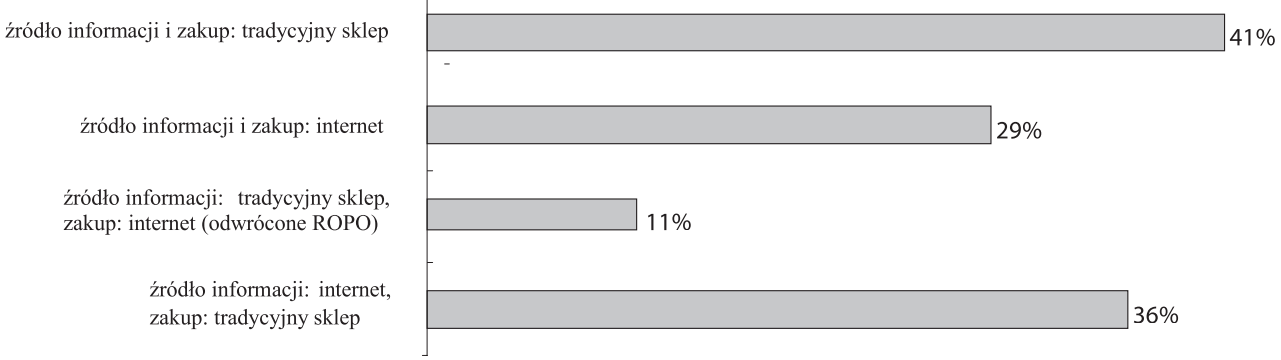

Źródło: opracowanie własne na podstawie danych Consumer Barometer (2015).

Analizując zachowania e-konsumentów, nie sposób pominąć istotnego, obserwowanego współcześnie trendu - zwiększania zakresu i częstotliwości wykorzystywania urządzeń mobilnych w procesach gromadzenia informacji i dokonywania zakupów w internecie. Trend ten jest istotny przede wszystkim dlatego, że stanowi swego rodzaju nową jakość w wykorzystaniu sieci teleinformatycznej w procesach nabywania dóbr i usług. Oferuje bowiem zarówno konsumentom, jak i sprzedawcom zupełnie nowe możliwości - od chociażby uniezależnienia możliwości przekazania lub/i pozyskania informacji oraz dokonania samego zakupu od miejsca pobytu konsumenta poprzez wykorzystanie geolokalizacji do uszczegółowienia pozyskiwanych lub przekazywanych informacji (rozszerzając zasięg efektu ROPO na wiele kategorii codziennych zakupów dóbr i usług), aż po płynne przenikanie i zatarcie granic pomiędzy fizycznym pobytem w tradycyjnym sklepie a zakupami on-line dzięki wykorzystaniu technologii tak zwanych beaconów - niewielkich nadajników (które mogą być rozmieszczone np. w sklepie) komunikujących się z urządzeniami mobilnymi. 
Chociaż zakupy przy wykorzystaniu urządzeń mobilnych stanowią w ujęciu wartościowym wciąż stosunkowo niewielką część zakupów internetowych (ok. 9\%), to dynamika wzrostu jest w ich przypadku znacznie wyższa niż w odniesieniu do ogółu zakupów on-line - w okresie ostatnich 4 lat wartość ta zwiększyła się prawie sześciokrotnie (tabela 4). Obecnie dokonywanie zakupów mobilnych deklaruje 1/4 użytkowników internetu i 1/3 posiadaczy urządzeń mobilnych. Wśród kategorii produktowych kupowanych z wykorzystaniem urządzeń mobilnych najbardziej popularne są urządzenia elektroniczne, odzież oraz usługi kulturalne i rozrywkowe (Mobile Institute, 2015). Można przy tym prognozować, że znaczenie specyficznych dla technologii mobilnej rozwiązań informacyjnych i informacyjno-dystrybucyjnych będzie się zwiększać równolegle ze wzrostem liczby użytkowników urządzeń mobilnych (aktualnie korzysta z nich 70\% internautów).

Tabela 4. E-zakupy dokonywane przy wykorzystaniu urządzeń mobilnych

\begin{tabular}{|l|c|c|c|c|c|}
\hline \multicolumn{1}{|c|}{ Wyszczególnienie } & 2011 & 2012 & 2013 & 2014 & 2015 \\
\hline Wartość m-zakupów [mln zł] & 390,0 & 700,0 & 1083,0 & 1485,3 & 2245,3 \\
\hline Wartość m-zakupów per capita [zł] & 10 & 18 & 28 & 39 & 58 \\
\hline
\end{tabular}

Źródło: opracowanie własne na podstawie danych Euromonitor (2015).

\section{Podsumowanie}

Zachowania nabywcze e-konsumentów są zjawiskiem o znacznej dynamice, podlegającym w swej relatywnie krótkiej historii istotnym zmianom dokonującym się wraz z szybko ewoluującą technologią teleinformatyczną. Współczesny obraz tych zachowań różni się więc znacząco od obserwowanego nawet kilka lat temu. Równolegle z upowszechnianiem się szerokopasmowego dostępu do internetu szybko wzrasta nie tylko wartość e-zakupów i odsetek konsumentów deklarujący ich dokonywanie, ale także (a może przede wszystkim) znaczenie internetu jako źródła informacji wykorzystywanych w procesie podejmowania decyzji zakupowych. Możliwości oferowane przez technologie teleinformatyczne (jak np. swoboda wymiany informacji, dostępność i łatwość porównywania ofert czy innowacyjne techniki komunikacji i modele dystrybucji) powodują przy tym, że internet staje się wygodnym instrumentem optymalizacji decyzji nabywczych e-konsumentów. Niewątpliwie szczególnie interesującym zjawiskiem jest tu hybrydowe wykorzy- 
stywanie w procesach decyzyjnych informacji pozyskanych w sieci i poza nią oraz hybrydowe wykorzystanie internetowych i tradycyjnych kanałów dystrybucji. Warto w tym kontekście zauważyć szybki rozwój technologii mobilnych oferujących jeszcze większe możliwości pod tym względem - od swobody dokonywania czynności komunikacyjnych i nabywczych w dowolnym miejscu i czasie, aż po płynne przenikanie i zacieranie granic pomiędzy pobytem w tradycyjnym sklepie a zakupami on-line.

\section{Literatura}

Consumer Barometer (2015). The Consumer Barometer Survey 2014/2015. Pobrane z: https://www.consumerbarometer.com (3.12.2015).

Euromonitor (2015). Pobrane z: http://www.portal.euromonitor.com (23.11.2015).

Gemius (2012). E-commerce w Polsce 2012 w oczach internautów. Pobrane z: https://www. ecommercepolska.pl (12.11.2015).

Gemius (2014). E-commerce w Polsce 2014. Gemius dla e-Commerce Polska. Pobrane z: http://www.infomonitor.pl (12.11.2015).

Gemius (2015). E-commerce w Polsce 2015. Gemius dla e-Commerce Polska. Pobrane z: https://www.gemius.pl (12.11.2015).

Goban-Klas, T., Sienkiewicz, P. (1999). Społeczeństwo informacyjne - szanse, zagrożenia, wyzwania, Kraków: Wyd. Fundacji Postępu Telekomunikacji.

GUS (2011). Społeczeństwo informacyjne w Polsce. Wyniki badań statystycznych z lat 2007-2011. Urząd Statystyczny w Szczecinie. Pobrane z: http://stat.gov.pl (15.11.2015).

GUS (2014). Społeczeństwo informacyjne w Polsce. Wyniki badań statystycznych z lat 2010-2014. Urząd Statystyczny w Szczecinie. Pobrane z: http://stat.gov.pl (15.11.2015).

GUS (2015). Wykorzystanie technologii informacyjno-(tele)komunikacyjnych $w$ gospodarstwach domowych w 2015 r. Pobrane z: http://stat.gov.pl (24.11.2015).

Jaciow, M., Wolny, R. (2011). Polski e-konsument. Typologia, zachowania. Gliwice: OnePress.

Kasriel-Alexander, D. (2015). Top 10 Global Consumer Trends for 2015. Euromonitor International. Pobrane z: http://go.euromonitor.com (9.11.2015).

Mobile Institute (2015). mShopper, Polacy na zakupach mobilnych. Pobrane z: https://www. ecommercepolska.pl (3.12.2015).

Opiniac (2015). Efekt ROPO w segmentach polskiego e-commerce-2015. Pobrane z: http:// opiniac.com (30.11.2015).

Tkaczyk, J. (2015). Źródła informacji w procesie podejmowania decyzji o zakupie przez e-konsumentów - Polska na tle innych państw UE. Marketing i Rynek, 8, 757-769. 


\title{
E-CONSUMERS' BUYING BEHAVIOURS IN POLAND
}

\begin{abstract}
E-consumers' buying behaviours are a dynamic phenomenon, changing significantly and simultaneously with fast evolving internet technology. The value of on-line purchases and the number of e-buyers is growing fast, as well as the significance of the internet as a source of information used by consumers in buying decision making process. The capabilities offered by new technologies make the internet a handy tool for optimizing the consumers' buying decisions. The paper aims to analyze the basic characteristics of polish e-consumers' behaviour and to identify trends in changes of these behaviours in recent years.
\end{abstract}

Translated by Mirosław Pacut

Keywords: consumer behaviour, e-consumer, buying behavior

JEL Codes: D12, D83 